\title{
ANTIBACTERIAL POTENTIAL OF KAPUL FRUIT SKIN (Baccaurea macrocarpa) ON Streptococcus sanguis
}

\author{
Norhayati*, Siti Ujrumiah*, Annisa Noviany*, Amy Nindia Carabelly**
}

\begin{tabular}{|c|}
\hline Keywords: \\
Antibacterials, Kapul \\
fruit skin (Baccaurea \\
macrocarpa), \\
Recurrent Aftosa \\
Stomatitis (SAR), \\
Streptococcus sanguis. \\
\hline
\end{tabular}

\section{ABSTRACT}

Introduction: Recurrent aphthous stomatitis $(S A R)$ is a recurrent ulceration lesion where many Streptococcus sanguis bacteria are found. Streptococcus sanguis bacteria can be killed by compounds that contain antibacterial. Kapul fruit (Baccaurea macrocarpa) is a typical Kalimantan fruit, has antioxidant and antibacterial activity which serves to kill Streptococcus sanguis. Method: Performed a quantitative phytochemical test on the kapul fruit peel and continued with the antibacterial activity test using the disc diffusion method of kapul fruit peel extract at the concentrations 20\%,40\%,60\%, 80\%, 100\%,Chlorhexidine as a positive control and aquades as a negative ( $n=4 /$ group). Result: From the phytochemical test, Kapul fruit peel extracts contain 35,851\% of alkaloid, 23,225\% of saponin, 2,395mg of tannin and 21,000mg of flavonoids. Kapul fruit peel extracts has the potential as an antibacterial against Streptococcus sanguis at concentration of $40 \%, 60 \%, 80 \%$ and $100 \%$. The concentration at $100 \%$ has an equivalent to chlorhexidine as an antibacterial potential. Conclusion: The potential of Kapul peel Extract as antibacterial to Streptococcus sanguis bacteria on $40 \%, 60 \%, 80 \%, 100 \%$ concentration. The concentration at $100 \%$ has an equivalent to chlorhexidine as an antibacterial potential.

\section{PENDAHULUAN}

Stomatitis Aftosa Rekuren (SAR) merupakan suatu lesi ulserasi yang terjadi secara berulang pada mukosa rongga mulut dengan gambaran klinis berupa ulser tunggal maupun multiple, dangkal, bulat lonjong, dan terasa sakit. ${ }^{1}$ SAR terjadi sekitar $20 \%$ dari populasi dan $2 \%$ diantaranya mengakibatkan rasa sakit yang hebat. Prevalensi SAR pada tahun 2014-2017 di Banjarmasin Kalimantan Selatan adalah 45, 42 $\% .^{2,3}$ Terdapat beberapa faktor pencetus yang dapat menyebabkan SAR, salah satunya adalah bakteri Streptococcus sanguis. ${ }^{4}$
Streptococcus sanguis merupakan bakteri gram positif anaerob fakultatif yang berperan sebagai bakteri pionir dalam proses kolonisasi bakteri yang ada di rongga mulut manusia dan sebagai agen penyebab terjadinya SAR. ${ }^{5}$ Bakteri ini sering dikaitkan dengan SAR baik sebagai patogen secara langsung atau sebagai stimulus antigenik dan mengakibatkan infeksi sekunder sehingga menyebabkan penyembuhan luka pada SAR terhambat. ${ }^{6}$

\footnotetext{
${ }^{*}$ Fakultas Kedokteran Gigi Universitas Lambung Mangkurat

${ }^{\star *}$ Departemen Biologi Oral, Fakultas Kedokteran Gigi, Universitas Lambung Mangkurat

Korespondensi: norhayati.27599@gmail.com
} 
Bakteri Streptococcus sanguis dapat dibunuh oleh senyawa yang mengandung antibakteri seperti Klorheksidin. ${ }^{8}$ Klorheksidin merupakan gold standard sebagai antibakteri terhadap berbagai macam bakteri. Namun Klorheksidin memiliki efek samping dalam penggunaan jangka panjang sehingga perlu alternatif lain yang berasal dari tanaman, salah satunya adalah buah Kapul. ${ }^{9}$

Buah kapul (Baccaurea macrocarpa) termasuk dalam buah endemik khas Kalimantan dan hanya terdapat di wilayah Kalimantan. Kulit buah kapul yang terbuang hanya akan menjadi limbah sehingga perlu dimanfaatkan. Berdasarkan hal tersebut penelitian ini dilakukan dengan tujuan menganalisis potensi antibakteri ekstrak kulit buah Kapul (Baccaurea macrocarpa) terhadap bakteri Streptococcus sanguis. ${ }^{7}$

\section{METODE PENELITIAN}

Penelitian ini menggunakan desain eksperimen laboratorium dengan posttest-only with control group design. Penelitian ini dilakukan di laboratorium Mikrobiologi dan Parasitologi Kedokteran Universitas Lambung Mangkurat pada bulan April-Juni 2019. Penelitian didahului dengan uji fitokimia ekstrak kulit buah Kapul, yang kemudian dilakukan pengujian aktivitas antibakteri ekstrak kulit buah kapul menggunakan metode difusi dengan konsentrasi $20 \%, 40 \%$, $60 \%, 80 \%$, 100\%, Klorheksidin sebagai kontrol positif dan Aquades sebagai kontrol negatif dengan empat kali pengulangan. ${ }^{15}$

\section{Ekstraksi Kulit Buah Kapul}

Ekstrak kulit buah Kapul dibuat dengan metode maserasi dengan menggunakan $1 \mathrm{~kg}$ kulit buah Kapul. Kulit buah Kapul dicuci terlebih dahulu, setelah itu di anginkan dan diletakan di nampan alumunium lalu dimasukkan di dalam oven dengan suhu $40^{\circ}-50^{\circ} \mathrm{C}$. Setelah kering lalu dihaluskan menggunakan blender dan diayak. Kemudian, timbang serbuk ekstrak kulit buah Kapul dan direndam dengan etanol 96\% selama 3 hari sambil diaduk dan jika sudah selesai lanjut dengan menyaring dan diuapkan menggunakan waterbath. ${ }^{11}$

\section{Uji Fitokimia Kulit Buah Kapul}

Uji Alkaloid. Uji ini menggunakan metode Gravimetri dengan cara menimbang ekstrak terlebih dahulu sebanyak $10 \mathrm{gr}$ lalu tambahkan $200 \mathrm{~mL}$ asam asetat $10 \%$ dalam etanol, diamkan selama 4 jam lalu saring dan seperempat ekstrak diuapkan di waterbath, tambahkan ammonium hidroksida dan cuci endapan dengan ammonium hidroksida. Residu yag dihasilkan merupakan alkaloid. ${ }^{12}$

Uji Saponin. Uji ini menggunakan metode Gravimetri dengan cara menimbang $10 \mathrm{gr}$ ekstrak lalu tambahkan $200 \mathrm{~mL}$ etanol $20 \%$, uapkan dengan waterbath dengan suhu $55^{\circ} \mathrm{C}$ selama 4 jam, kemudian saring larutan dan residu diekstrak lagi dengan menguapkan di waterbath pada suhu $90^{\circ} \mathrm{C}$ hingga menjadi $40 \mathrm{~mL}$, konsentrat dituang dalam corong pisah dan ambil lapisan air lalu tambahkan $60 \mathrm{~mL}$ n-butanol, cuci dengan $10 \mathrm{~mL}$ $\mathrm{NaCL} 5 \%$ dan uapkan. ${ }^{12}$

Uji Tannin. Uji ini menggunakan metode Spektrofotometri dengan cara ekstrak ditimbang sebanyak $10 \mathrm{gr}$ dilarutkan dengan aquades lalu ambil 50 $\mu \mathrm{L}$, tambahkan $400 \mu \mathrm{L} \mathrm{K}_{4} \mathrm{Fe}(\mathrm{CN})_{6} 0,8 \mathrm{mM}$ $+400 \mu \mathrm{L} \mathrm{FeCl}{ }_{3}$ 0,1 M dalam $\mathrm{HCL} 0,1 \mathrm{M}$, tambahkan aquades hingga larutan menjadi $10 \mathrm{ml}$ 
dan biarkan selama 7 menit, kemudian ukur absorbsinya. ${ }^{13}$

Uji Flavonoid. Uji ini dilakukan dengan metode Spektofotometri yaitu beberapa tetes larutan $\mathrm{NaOH}$ ditambahkan ke ekstrak kulit buah kapul sebanyak $500 \mu \mathrm{l}$, ditambahkan HCL saat larutan berubah menjadi warna kuning dan kemudian tidak berwarna yang menandakan adanya flavonoid. ${ }^{14}$

\section{Uji Antibakteri Kulit Buah Kapul}

Metode yang digunakan untuk uji antibakteri kulit buah kapul adalah metode difusi cakram. Perlakuan menggunakan ekstrak kulit buah kapul dengan konsentrasi $20 \%, 40 \%, 60 \%$, $80 \%, 100 \%$, Klorheksidin sebagai kontrol positif dan Aquades sebagai kontrol negatif.

Pertama ekstrak diencerkan terlebih dahulu, lalu disk direndam di dalam ekstrak kulit buah kapul selama 3 jam. Setelah 3 jam, disk diletakkan pada media uji yang sudah diberi bakteri Streptococcus sanguis yang kemudian di inkubasi selama 24 jam. Setelah 24 jam, dilakukan pengukuran zona hambatnya yaitu berupa zona bening disekitar disk menggunakan kaliper. ${ }^{16}$

\section{HASIL PENELITIAN}

Pengujian antibakteri kulit buah Kapul terhadap bakteri Streptococcus sanguis sudah lulus etik No. 185/KEPKG-FKGULM/EC/V/2019 dari Fakultas Kedokteran Gigi Universitas Lambung Mangkurat Banjarmasin.

Hasil uji fitokimia kulit buah Kapul dapat dilihat pada tabel dibawah ini :

Tabel 1. Hasil Uji Fitokimia Ekstrak Kulit Buah Kapul

\begin{tabular}{ll}
\hline Senyawa & Mean \pm SD \\
\hline Alkaloid & $38,85 \pm 0.61$ \\
Saponin & $23,22 \pm 1.02$ \\
Flavonid & $21,00 \pm 0,66$ \\
Tannin & $2.39 \pm 0.00$ \\
\hline
\end{tabular}

Tabel 2. Rata-rata daya hambat ekstrak kulit buah Kapul terhadap bakteri Streptococcus sanguis.

\begin{tabular}{ccc}
\hline Konsentrasi(\%) & $\mathrm{N}$ & $\begin{array}{c}\text { Mean } \pm \text { Standar } \\
\text { Deviasi }\end{array}$ \\
\hline $20 \%$ & 4 & $0,37 \pm 0,09$ \\
$40 \%$ & 4 & $0,97 \pm 0,50$ \\
$60 \%$ & 4 & $1,10 \pm 0,08$ \\
$80 \%$ & 4 & $1,45 \pm 0,57$ \\
$100 \%$ & 4 & $1,77 \pm 0,05$ \\
$\mathrm{~K}$ & 4 & $1,72 \pm 0,12$ \\
$\mathrm{~A}$ & 4 & $0,30 \pm 0,00$ \\
\hline
\end{tabular}

Tabel 2 menunjukkan bahwa semakin besar konsentrasi maka semakin besar pula kemampuan daya hambat antibakteri kulit buah kapul.

Gambar 1. Hasil Uji Aktivitas Anti Bakteri Kulit Buah Kapul (Baccaurea macrocarpa) terhadap bakteri Streptococcus sanguis.

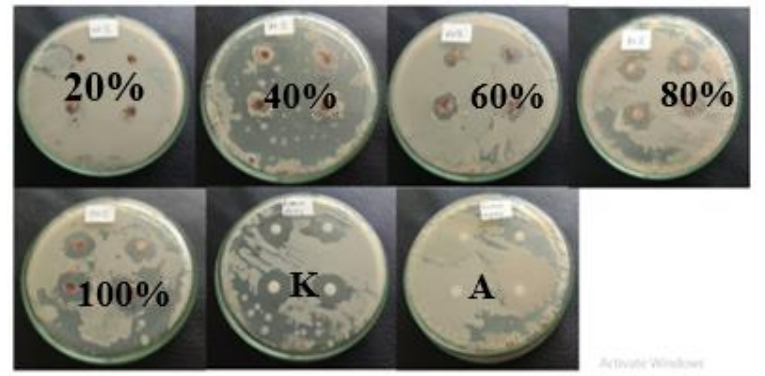

Shapiro wilk dengan hasil $p<0.05$ yang menunjukkan data terdistrubusi tidak normal. Uji dilanjutkan dengan uji Kruskal- wallis didapatkan $p=0,017$ yang berarti terdapat perbedaan bermakna. Uji dilanjut dengan uji Mann Whitney yang dapat dilihat pada tabel di bawah ini. 
Tabel 3. Uji statistic Mann - Whitney

\begin{tabular}{cccccccc}
\hline Konsentrasi & $20 \%$ & $40 \%$ & $60 \%$ & $80 \%$ & $100 \%$ & $\mathrm{~K}$ & $\mathrm{~A}$ \\
\hline $20 \%$ & & $0,017^{*}$ & $0,019^{*}$ & $0,019^{*}$ & $0,017^{*}$ & $0,019^{*}$ & 0,131 \\
$40 \%$ & $0,017^{*}$ & & $0,044^{*}$ & $0,017^{*}$ & $0,015^{*}$ & $0,017^{*}$ & $0,011^{*}$ \\
$60 \%$ & $0,019^{*}$ & $0,044^{*}$ & & $0,019^{*}$ & $0,017^{*}$ & $0,019^{*}$ & $0,013^{*}$ \\
$80 \%$ & $0,019^{*}$ & $0,017^{*}$ & $0,019^{*}$ & & $0,017^{*}$ & $0,019^{*}$ & $0,013^{*}$ \\
$100 \%$ & $0,017^{*}$ & $0,015^{*}$ & $0,017^{*}$ & $0,017^{*}$ & & 0,363 & $0,011^{*}$ \\
$\mathrm{~K}$ & $0,019^{*}$ & $0,017^{*}$ & $0,019^{*}$ & $0,019^{*}$ & 0,363 & & $0,013^{*}$ \\
$\mathrm{~A}$ & 0,131 & $0,0111^{*}$ & $0,013^{*}$ & $0,013^{*}$ & $0,0111^{*}$ & $0,013^{*}$ & \\
\hline
\end{tabular}

Keterangan :

* = Terdapat perbedaan yang

Signifikan $(p<0,05)$

$\mathrm{K}=$ Klorheksidin

$\mathrm{A}=$ Aquades

\section{DISKUSI}

Hasil uji fitokimia menunjukkan bahwa kulit buah Kapul mengandung senyawa alkaloid sebesar $35.851 \%$, saponin sebesar $23.225 \%$, flavonoid sebesar $21.000 \mathrm{mg} / \mathrm{mL}$. dan tannin $2.395 \mathrm{mg} / \mathrm{mL}$.

Penelitian antibakteri kulit buah Kapul menunjukkan bahwa ekstrak kulit buah kapul dengan konsentrasi $40 \%, 60 \%$, 80\% dan $100 \%$ memiliki kemampuan antibakteri terhadap bakteri Streptococcus sanguis, dimana kemampuan antibakteri terbesar terdapat pada konsentrasi $100 \%$. Hal ini, sesuai dengan penelitian sebelumnya yang menyatakan bahwa semakin tinggi konsentrasi ekstrak maka semakin tinggi pula jumlah senyawa atau kandungan zat aktif di dalamnya. ${ }^{17}$

Kulit buah Kapul (Baccaurea macrocarpa) merupakan salah satu tanaman yang mempunyai aktivitas antioksidan dan antibakteri karena mengandung senyawa metabolit sekunder seperti alkaloid, saponin, tannin dan flavonoid yang berfungsi sebagai antibakteri. ${ }^{10}$
Saponin dapat mengganggu pertumbuhan dan perkembangan bakteri dengan cara menekan dinding sel bakteri, selain dapat mengakibatkan terganggunya pertumbuhan dan perkembangan bakteri, dinding sel yang tertekan dapat mengakibatkan kematian pada bakteri dikarenakan metabolisme bakteri yang terganggu. ${ }^{18}$ Saponin mengakibatkan kebocoran senyawa intraseluler karena memicu terjadinya penurunan pada tegangan permukaan sel bakteri dan menambah permeabilitas sel. ${ }^{21}$ Saponin sendiri terdapat pada bagian tanaman yang memiliki kemampuan untuk pertahanan seperti kulit buah. ${ }^{22}$

Alkaloid yang merupakan senyawa metabolit sekunder dapat ditemukan pada tanaman, dimana alkaloid memiliki kemampuan untuk membunuh sel bakteri dengan cara mengganggu proses pembentukan peptidoglikan pada dinding sel bakteri sehingga dinding sel bakteri tidak terbentuk dengan sempurna yang berakibat sel mengalami kematian atau nekrosis. ${ }^{23}$ Alkaloid juga bisa mengganggu komponen penyusun peptidoglikan pada sel bakteri yang akibatnya sama seperti sebelumnya yaitu dinding sel bakteri tidak terbentuk sempurna dan akan mengalami kematian. ${ }^{24}$

Tanin tergolong senyawa yang memiliki kemampuan mengganggu pertumbuhan bakteri dengan cara mengikat protein pembentuk dinding sel yang berakibat pertumbuhan dinding sel terhambat. Mekanisme tanin yaitu dinding sel yang telah lisis akibat senyawa saponin dan flavonoid menyebabkan senyawa tanin mudah masuk ke dalam sel dan mengkoagulasi protoplasma sel bakteri. ${ }^{19}$ Tanin memiliki kemampuan toksisitas dengan cara membentuk 
ikatan kompleks ion logam yang beakibat terjadinya kerusakan pada membran sel bakteri. ${ }^{24}$

Flavonoid merupakan senyawa yang memiliki kemampuan sebagai antivirus dan antiinflamasi. $^{20}$ Senyawa flavonoid memilki kemampuan untuk merusak membrane sel bakteri yang berakibat cairan intraseluler keluar dari dalam sel bakteri. flavonoid memiliki kemampuan sebagai inhibisi pada sintesis DNA RNA ikatan hidrogen dengan penumpukan basa asam nukleat. Flavonoid juga berperan dalam menghambat metabolisme energy. ${ }^{21}$ Senyawa flavonoid bersifat antibakteri dengan membuat sintesis asam nukleat, membrane sel dan metabolisme energy menjadi terhambat. Mekanisme kerja flavonoid dalam menghambat sintesis asam nukleat dilakukan melalui cincin B pada flavonoid yang mempunyai peranan penting dalam proses interkalasi atau ikatan hidrogen dengan menumpuk basa asam nukleat yang menghambat sintesis DNA dan RNA. ${ }^{24}$

Ekstrak kulit buah Kapul konsentrasi $40 \%, 60 \%, 80 \%$ dan $100 \%$ terbukti bersifat antibakteri terhadap bakteri Streptococcus sanguis. Ekstrak kulit buah Kapul konsentrasi $100 \%$ berpotensi antibakteri yang setara dengan Klorheksidin. Ekstrak kulit buah Kapul berpotensi untuk dikembangkan sebagai salep antibakteri yang dapat mempercepat penyembuhan luka SAR.

\section{KESIMPULAN}

Ekstrak kulit buah Kapul berpotensi
sebagai antibakteri terhadap bakteri
Streptococcus sanguis pada konsentasi $40 \%$,
$60 \%, 80 \%, 100 \%$, dan konsentrasi $100 \%$

berpotensi antibakteri yang setara dengan klorheksidin.

\section{UCAPAN TERIMA KASIH}

Penelitian ini dilakukan dengan menggunakan dana dari Ditjen Simbelmawa,

\section{DAFTAR PUSTAKA}

1. Apriasari ML, Fadhillah A, Carabelly AN. Aktivitas antibakteri ekstrak metanol batang pisang Mauli (Musa sp) terhadap Streptococcus mutans. Dentofasial. 2013; 12 (3): 148-151.

2. Hatta I, KF I Wayan A, Apriasari ML. The Prevalence of Oral Mucosa Disease of Gusti Hasan Aman Dental Hospital In Banjarmasin, South Kalimantan. Dentino Jurnal Kedokteran Gigi. 2018; 3(2): 211-212.

3. Yogasedana IMA, Mariati, Leman NW, Michael A. Angka Kejadian Stomatitis Aphtosa Rekuren (SAR) Ditinjau dari Faktor Etiologi di RSGM FK UNSRAT. Jurnal e-Gigi (eG). 2015; 3(2): 278-279.

4. Sulistiani A, Hernawati S, Mashartini AP. Prevalensi dan Distribusi Penderita Stomatitis Aftosa Rekuren (SAR) di Klinik Penyakit Mulut RSGM FKG Universitas Jember Pada Tahun 2014. E- Jurnal Pustaka Kesehatan. 2014;596-597.

5. Attamimi FA, Ruslami R, Maskoen AM. Uji Aktivitas Antibakteri Ekstrak Kasar Umbi Sarang Semut (Myrmecodia pendens) Dibanding dengan Klorheksidin terhadap Streptococcus sanguinis. MKB. 2017; 49(2): 95. 
6. Wololy J, Kepel BJ, Mintjelungan CN. Gambaran Pengetahuan Masyarakat Desa wiau Lapi tentang Stomatitis Aftosa Rekuren. Jurnal Biomedik (JBM). 2013; 5(1): 97-99.

7. Zein RB. Classification, Epidemiologi and Aetiologi of Oral Recurrent Afthous Stomatitis. Annal Dent. 1999; 6: 35-38.

8. Sinaredi BR, Pradopo S, Wibowo TB. Daya Antibakteri Obat Kumur Chlorheksidin, Providone lodine, Flouride Suplementasi Zinc terhadap Streptococcus mutans dan Porphyromonas gingivalis. Dental Jurnal. 2014; 47(4): 212.

9. Madiyawati M, Penyang, Fauzi F, Triyadi A. Karakteristik dan Uji Fitokimia 5 (Lima) Jenis Tumbuhan Buah Eksotik dari Kabupaten Barito Utara Kalimatan Tengah. 2018. Jurnal Daun; 4(1): 51.

10. Akhmadi NR, Sumarmiyati. Eksplorasi dan Karakterisasi Buah Kapul (Baccaurea macrocarpa) di Kabupaten Kutai Barat, Kalimantan Timur. Pros Sem Nas Masy Biodiv Indon. 2015; 1(4): 923-924.

11. Fajeriyati $\mathrm{N}$, Andika. Uji Aktivitas Antibakteri Ekstrak Etanol Rimpang Kencur (Kaempferia galanga L.) pada Bakteri Bacillus subtilis dan Escherichia coli (Antibacterial Activity of Ethanol Extract of Kencur Rhizome (Kaempferia galanga L.) in Bacillus subtilis and Escherichia coli). Journal of Current Pharmaccutical Sciences. 2017; 1(1): 39.

12. Edeoga HO, Okwu DE, Mbaebie BO. Phytochemical Constituent of Some Nigerian Medical Plant. African Journal of Biotecnology. 2005; 4(7): 685-688.

13. Purwaningdyah YG, Widyaningsih TD, Wijayanti N. Efektivitas Ekstrak Biji Pepaya Sebagai Antidiare pada Mencit yang Diinduksi
Salmonella thyphimurium. Jurnal Pangan dan Agroindustri. 2015; 3(4): 1283-1293.

14. Devanoboyina N, Laksmi RN, Styanarayana B. Prelimminary Phytochemical Screening Qualitatif and Evaluatif of Antimicrobial Activity of Alstoniamachrophylla Stem Bark. International Journal of Science Invention Today. 2013; 2(1): 31-39.

15. Novita W. Uji Aktivitas Antibakteri Fraksi Daun Sirih (Piper Betle L) terhadap Pertumbuhan Bakteri Streptococcus mutans secara In Vitro. JMJ. 2016; 4(2):142.

16. Angraini F, Satari MH, Mariam MS. Bacterial inhibition test of methanolic extract of srawberry (fragaria x ananassa Duchesne), lime (Citrus aurantifolia), and radish (Raphanus sativus L.), towards Streptococcus sanguis ATCC 10556. Padjajaran J Dent. 2018; 30(2): 98-102.

17. Zakki M. Uji aktivitas antibakteri ekstrak cathechin tejh putih terhadap Streptococcus sanguinis.ODONTO Dental Journal. 2017; 4(2): 108-112.

18. Madduluri, Suresh. Rao, K.Babu. Sitaram, B. In Vitro Evaluation of Antibacterial Activity of Five Indegenous Plants Extract Against Five Bacterial Pathogens of Human. International Journal of Pharmacy and Pharmaceutical Sciences.2013;5(4): 679-684.

19. Nuria, Cut M, Faizaitun, Arvin, Sumantri. Uji Aktivitas Antibakteri Ekstrak Etanol Daun Jarak Pagar (Jatropha Curcas L) terhadap Bakteri Staphylococcus Aureus, Escherichia Coli dan Salmonella Typhi. Mediagro. 2009;5(2):26-37.

20. Arifin B, Ibrahim S. Struktur Bioaktivitas dan Antioksidan Flavonoid. Jurnal Zarah. 2018; 6(1): 21. 
21. Ngajow M, Abidjulu J, Kamu VS. Pengaruh Antibakteri Ekstrak Batang Matoa (Pometia pinnata) terhadap Bakteri Staphylococcus aures secara In Vitro. Jurnal Mipa UNSRAT Online. 2013; 2(2): 131.

22. Hidayah N. Pemanfaatan Senyawa Metabolit Sekunder Tanaman ( Tanin dan Saponin) dalam Mengurangi Emisi Metan ternak Ruminansia. Jurnal Sain Peternakan Indonesia. 2016; 2(2): 92-95.

23. Aksara R, Musa JAW, Alio L. Identifikasi Senyawa Alkaloid Dari Ekstrak Metanol Kulit Batang Mangga (Mangifera indica L). Jurnal Entropi. 2013; 8(1): 515-516.

24. Rahman FA, Haniastuti T, Utami TW. Skrining fitokimia dan aktivitas antibakteri ekstrak etanol daun sirsak (Annona muricata L.) pada Streptococcus mutans. Majalah Kedokteran Gigi Indonesi 2017; 3(1): 3-6.

25. Thantawi A, Khairiati, Nova MM, Bakar A. Stomatitis Aftosa Rekuren (SAR) Minor Multiple Pre Menstruasi (Laporan Kasus). ODONTO dental Journal. 2014; 1(2): 57.

26. Bazrafshani MR, Hajeer AH, Ollier WER, Thornhill MH. Polymorphism in the il- 10 and il- 12 Gene Cluster and Risk of Developing Recurrent Aphthous Stomatitis. Oral Disease Journal. 2003; 9: 91-287. 